\title{
Validity of Light Transmittance to Predict Soil Hydraulic Conductivity in Salt-Affected Soils
}

\author{
M. S. Shams ${ }^{(1)^{*}}$, A. A. Aboushal ${ }^{(2)}$, M. M. Saffan ${ }^{(1)}$, M. A. \\ El-Kammah $^{(1)}$, K. Rateb ${ }^{(2)}$ and H. R. El-Ramady ${ }^{(1)}$ \\ ${ }^{(1)}$ Department of Soil and Water Science, Faculty of \\ Agriculture, Kafrelsheikh University, Egypt ${ }^{(2)}$ Institute of Soil, \\ Water, and Environmental Research, Agricultural Research \\ Center, Egypt
}

\begin{abstract}
LAY dispersion and flocculation are very common processes in salt-affected soils and have a direct impact on the movement of water and dissolved ions. This study was aimed to make use of light transmittance $(\% \mathrm{~T})$ through soil suspension as a monitor and to reflect the intensity of dispersed clay particles as it relates to hydraulic conductivity (K), and percent of clay dispersion. To achieve this aim, two soils with varied clay contents, were collected from Beheira (S1) and Gharbia (S2) Governorates in north of Nile Delta, Egypt, and treated with sodium $(\mathrm{Na})$, calcium $(\mathrm{Ca})$, and magnesium $(\mathrm{Mg})$ chlorides to obtain combinations of sodium adsorption ratio (SAR) and electrical conductivity (EC) treatments. Measurements of K and T might be affected by exchangeable cations and correlated negatively with SAR. Results showed that values of $\mathrm{T}$ were decreased continually (tendency to clay dispersion), that might be a good indicator for changes of K. Relations between T, K and SAR indicated high clay dispersion and low $\mathrm{K}$ as SAR increased. The empirical equations derived from both $\mathrm{K}$ and $\mathrm{T}$ measurements may introduce a new approach to predict $\mathrm{K}$, taking into consideration the clay content, EC and SAR of the soils. Promising results were obtained when these equations were subjected to evaluation, using 15 various soil samples with high correlation coefficient of determined versus estimated $\mathrm{K}\left(\mathrm{R}^{2}\right.$ $=98 \%)$. Calculation of dispersion (\%) for SAR-EC treatments, using $\mathrm{T}$ and standard clay curve (\% $\mathrm{T}$ versus clay content) showed that soil aggregates are not always stabilizing by an increase of sodium ions and it is not needed to reach complete clay dispersion to clog the conducting pores and loss of water permeability. Dispersion percent decreased within a given SAR as EC increased due to the adverse effect of salinity (tendency to accumulation) on sodicity.
\end{abstract}

Keywords: Hydraulic conductivity, Light transmittance, Sodium adsorption ratio, Soil salinity

There are some studies concerning the soil hydraulic conductivity under salinity and sodicity soils (Seifert et al. 2011; Ezlit et al. 2013; Callaghan et al. 2014). The dominant processes in reducing permeability of the arid zone soils is clay dispersion followed by migration of clay and plugging of soil pores (Frenkel 
et al. 1978). Clay dispersion depends partially on the thickness of the electrical double layer, which is related to clay mineralogy, type of exchangeable ions and concentration of the electrolyte (Sumner 1993). Coagulation, that produces bulky and settled masses of particles with high water contents, is dependent on the surface chemistry and geometry of the colloids involved, as well as on $\mathrm{pH}$, ionic strength, and composition of the soil solution (Sposito 1984). Light scattering or light transmittance $(\mathrm{T})$ in clay suspension measurements offers a very simple and convenient method for determining the size of colloidal dispersed particles (Shainberg and Kaiserman 1969; Evangelou and Marsi 2003; Tedeschi and Dell'Aquila 2005) considered that high values of exchangeable sodium percent (ESP) caused a breakdown of the aggregates into elementary particles by physicochemical dispersion. The effects of clay minerals, composition, and salinity of solution on $\mathrm{Na}-\mathrm{Ca}$ exchange selectivity of montmorillonite and illite were studied by (Endo et al. 2002). Compared with montmorillonite, the affinity of illite for $\mathrm{Na}$ was high and decreased with increasing clay content. This phenomenon was obvious at the low SAR and high salinity of equilibrated solutions, based on colloidal properties. These findings suggest that the affinity of the soil for $\mathrm{Na}$ increases with soil salinization. Levy et al. (2003 and 2005) studied the combined effects of salinity, sodicity, wetting rate, and soil texture on hydraulic conductivity $(\mathrm{K})$ and aggregate stability. They found that wetting rate has no effect on aggregate slaking of soils with low clay content $(\sim 9 \%)$. As clay content increases, there is a significant interaction among the treatment variables affecting $\mathrm{K}$ and aggregate stability. The flocculation- dispersion behavior of the clay is usually studied using $\mathrm{Na}-\mathrm{Ca}$ electrolytes having various levels of electrolyte concentration and SAR (Arora and Coleman 1979; Abu-Sharar 1988; Goldberg and Forster 1990; Curtin et al. 1994). Dispersion of clay and its subsequent plugging in soil pores is responsible for loss in soil hydraulic conductivity (K). Moreover, exchangeable cations, electrolytes composition and concentration and soil texture are factors affected K measurements (Quirk and Schofield 1955; McIntyre 1979; Levy et al. 2003 and 2005).

The main objectives of this study were:

1) The validity of light transmittance measurements (\% T), as an indicator, through soil suspension of $\mathrm{Na}-\mathrm{Ca}$ and $\mathrm{Mg}$ soil combination treatments to predict parameters related to dispersion and flocculation of soil clay, i.e. K.

2) The role of clay dispersion percent (DP) as affected by SAR and EC treatments on loss of water permeability using $\mathrm{T}$ approach.

\section{Materials and Methods}

\section{Soil sampling and preparation}

Two surface agricultural soil samples $(0-30 \mathrm{~cm})$ was collected from AlRahmania (S1), Beheira Governorate and the farm of Al-Gemmeza (S2), Agriculture Research Station, Gharbia Governorate, in north of Nile Delta, Egypt $\left(30.61^{\circ} \mathrm{N} 30.43^{\circ} \mathrm{E}\right.$ and $30.47^{\circ} \mathrm{N} 31.00^{\circ} \mathrm{E}$, respectively). Soils were air-dried and passed through $0.2 \mathrm{~mm}$ sieve and stored to be ready for analysis. Particle size distribution was determined by the hydrometer. Total $\mathrm{CaCO}_{3}$ was determined volumetrically by means of Collin's calcimeter method (Sparks et al. 1996). Soil Egypt. J. Soil. Sci. 56, No. 4 (2016) 
$\mathrm{pH}$, EC, soil organic matter and water soluble cations and anions were determined (Page et al. 1982). Cation exchange capacity (CEC) was measured by sodium acetate method as described by Sumner and Miller (1996).

\section{SAR-EC combinations}

The soil was sodified to six SAR levels (5, 10, 15, 20, 25 and 30). Soil samples $(10 \mathrm{~kg})$ were spread over plastic sheet. Calculated amounts of sodium bicarbonate for each treatment were added to the soil with distilled water to keep moisture content at $40 \%$ of field capacity (FC), to avoid loss of added saline solution. After two weeks, the soil was sprayed with distilled water (3 times) to attain the chemical equilibrium between solid and liquid phases. Soil treatments were air dried and ready to receive salinization levels. The SAR of different saturation extracts was found to be around $95-96 \%$ of the desired sodicity level. The soils were salinized to five salinity levels $\left(3,6,9,12\right.$ and $\left.15 \mathrm{dS} \mathrm{m}{ }^{-1}\right)$ for each $\mathrm{SAR}$ treatment. Amounts of $\mathrm{Ca}, \mathrm{Mg}$ and $\mathrm{Na}$ salts required to raise the salinity to the specified level at given SAR were sprayed on the spread soil layer. The added $\mathrm{Na}$, $\mathrm{Ca}$ and $\mathrm{Mg}$ chloride salts are calculated using special computer program designed by the research team, to calculate weights of added salts at given SAR/EC treatments. Basically a second order linear equation is used to calculate amounts of $\mathrm{Na}, \mathrm{Ca}$ and $\mathrm{Mg}$ salts by the computer program. The procedure is repeated for the EC treatments, air dried, sieved and stored to be ready for analysis.

Similar experiments were performed to obtain combination of $\mathrm{Na}-\mathrm{Ca}$ (no $\mathrm{Mg}^{++}$is added) and $\mathrm{Na}-\mathrm{Mg}$ (no $\mathrm{Ca}^{++}$is added) treatments. The proper wavelength for colorimetric determination was determined by plotting optical absorbance (A) against wavelengths for soil suspension. Maximum absorbance (A) was displayed at $480 \mathrm{~nm}$ wavelength. All treatments had three replications.

\section{Dispersion measurement}

Three soil suspensions were carried out to select the most reliable one. Combinations of SAR-EC soil treatments are used. Three calculated soil weights were used to contain three levels of clay fraction $(<2 \mu \mathrm{m})$. Soil weights were 6.67, 3.33, and $1.67 \mathrm{~g}$ which contain 1.0, 0.5, and $0.25 \mathrm{~g}$ clay of Al-Rahmania soil (S1). The corresponding weights for Al-Gemmeza soil (S2) were 2.86, 1.43, and $0.71 \mathrm{~g}$. Deionized water was added to reach the volume of one liter. The suspension was mixed by plunger several times and allowed settling for $7 \mathrm{~h}$; the time was calculated according to Stock's' law for clay size dimension $(2 \mu \mathrm{m})$ at $10 \mathrm{~cm}$ depth. Aliquot $(5 \mathrm{ml})$ of suspension was withdrawn at $10 \mathrm{~cm}$ depth using automatic pipette (Curtin et al. 1994). Optical transmittance (\% T) was recorded at $480 \mathrm{~nm}$ wavelength using a $21 \mathrm{D}$ spectrophotometer.

Optical $\mathrm{T}$ is used to estimate clay concentration $\left(\mathrm{g}^{-1}\right)$ for a given treatment, after establishing clay concentration versus optical $\mathrm{T}$ standard curve. The curve is constructed using untreated Al-Gemmeza soil (S2), $0.03-0.36 \mathrm{~g}$ clay. The soil samples are placed in a dispersing cup with $400 \mathrm{ml}$ of distilled water and $2 \mathrm{ml}$ of $0.5 \mathrm{~N}$ sodium meta-phosphate which is used as dispersing agent. The suspension 
was stirred for $5 \mathrm{~min}$ and transferred to the sedimentation cylinder and distilled water was added to reach one liter. The contents were thoroughly mixed by plunger and allowed to settle for $7 \mathrm{~h}$. Aliquot was withdrawn at $10 \mathrm{~cm}$ depth to measure optical T at $480 \mathrm{~nm}$ wavelength. Saturated hydraulic conductivity (K) was measured using variable head (Klute 1986).

\section{Sodium-saturated soil}

This procedure was carried out to calculate clay dispersion percent (DP). Soil samples were leached with enough quantity of sodium chloride solution $1 \mathrm{~N}$, after organic matter destruction with $\mathrm{H}_{2} \mathrm{O}_{2}$. Excess $\mathrm{Cl}^{-}$was removed by washing soil suspension with ethanol to reach free chloride condition using silver nitrate. $\mathrm{Na}$ saturated soil was dried to be ready for $\% \mathrm{~T}$ measurement of maximum soil dispersion. Dispersion percentage (DP) was calculated according to the following equation:

$$
\mathrm{DP}=\mathrm{W}^{*} 100 / \mathrm{W}_{\mathrm{m}}
$$

where, $\mathrm{W}$ is weight of dispersed clay at a given treatment and $\mathrm{W}_{\mathrm{m}}$ refers to weight of clay at maximum dispersion (Na-saturated soil).

\section{Statistical analysis}

Statistical analyses was performed using the analysis of variance (ANOVA) and Duncan's multiple range tests to compare the means of the treatments at a level of significance of $p<0.05$.

\section{Results AND Discussion}

\section{Characterization of the studied soils}

Basic properties of the studied soils are presented in (Table 1). The two soils showed a different particle size distribution, S1 is dominated by sand and low clay, whereas S2 is characterized by high clay. Silt fraction is approximately similar in the two soils. Both soils have basic nature and low organic matter content. No varied distinction, in clay mineral content was observed with S1 and S2. Averages of clay minerals percentage are: Montmorillonite, 52; Illite. 25; Kaolinite, 13 and Chlorite, 10 (Mashali 1987). The two soils were classified as Typic Xerofluvent for (S1), and as Typic Ustifluvent for (S2), according to Soil Survey Staff (2010).

$\mathrm{Na}-\mathrm{Ca}-\mathrm{Mg}$ soil system

Soil suspension of $0.5 \mathrm{~g}$ soil $\mathrm{l}^{-1}$ has been used in the present study, due to readings of $\mathrm{T}$ were reliable. Combined treatments of SAR-EC were carried out for each soil; therefore, variation due to clay minerals is neglected. It is important, at the beginning, to define that, high reading of $\% \mathrm{~T}$ corresponds to flocculation (accumulation) and low reading corresponds to dispersion. Results of \% T for S1 (15\% clay) and S2 (35\% clay), showed a general trend with Na$\mathrm{Ca}-\mathrm{Mg}$ treatments (Figs. 1 and 2), i.e., at given soil EC, \% $\mathrm{T}$ decreased with increasing SAR. Such decrease was gradual and did not show a noticeable or sudden optical $\mathrm{T}$ reduction in $\mathrm{S} 1$. The drop of $\% \mathrm{~T}$ reading with $\mathrm{S} 2$ was at SAR Egypt. J. Soil. Sci. 56, No. 4 (2016) 
of 19. The gradual decrease of $\% \mathrm{~T}$ as $\mathrm{SAR}$ increased might be due to insufficient sodium ions to overcome the forces binding clay particles, and preventing aggregates to further dispersion (Hanson et al. 1999; Falstad 2000; Nikos et al. 2003). On the other hand, calcium and magnesium tend cluster closer to the clay particles. Optical $\mathrm{T}$ approach allows following up such $\mathrm{Na}$ induced dispersion i.e., decrease of light transmission readings as SAR increased.

Elevated salt concentrations in the soil solution slightly promote clay particles to aggregate; this trend is following up using $\mathrm{T}$ approach. The effect of salinity on dispersion might be explained as follows: The counter ions or cations balancing the negative charge are influenced by two countervailing forces, the electrical force attracting the positive ion to the negative surface and the diffusive or thermal forces (Brownian motion) which facilitate the movement of the cations away from the surface. The balance of these two forces gives rise to a distribution of cations in water adjacent to the clay surface (Agassi 1996; Quirk 2003). Optical T measurements showed slight sensitivity to display the complex effect of both salinity and sodicity with Al-Rahmania soil (S1), due to its lower clay content $(15 \%)$. It seems that validity of optical $\mathrm{T}$ approach to monitor flocculation and dispersion of soil suspension is associated partly with clay content as well as type of exchangeable cations.

TABLE 1. Some physical and chemical characteristics of the studied soils

\begin{tabular}{|c|c|c|}
\hline Characteristic & $\begin{array}{l}\text { Al-Rahmania Soil } \\
\text { (S1) }\end{array}$ & $\begin{array}{c}\text { Al-Gemmeza Soil } \\
\text { (S2) }\end{array}$ \\
\hline Saturation percent & 37.0 & 63.4 \\
\hline Field capacity, $\%$ & 18.5 & 31.7 \\
\hline $\mathrm{pH}, 1: 2.5^{*}$ & 8.4 & 8.3 \\
\hline $\mathrm{EC}, \mathrm{dS} \mathrm{m}^{-1}$ & 1.4 & 2.1 \\
\hline Soil Organic Mater, $\mathrm{g} \mathrm{kg}^{-1}$ & 7.5 & 12.5 \\
\hline SAR & 2.68 & 4.80 \\
\hline $\mathrm{CEC}, \mathrm{cmol}_{\mathrm{c}} \mathrm{kg}^{-1}$ & 31.0 & 63.0 \\
\hline $\mathrm{CaCO}_{3}, \%$ & 3.5 & 2.3 \\
\hline \multicolumn{3}{|l|}{ Particle size distribution } \\
\hline Sand, $\%$ & 63.0 & 41.0 \\
\hline Silt, \% & 22.0 & 24.0 \\
\hline Clay, \% & 15.0 & 35.0 \\
\hline Textural Class & Sandy loam & Clay loam \\
\hline \multicolumn{3}{|l|}{ Soluble cations, $\mathrm{mmol} \mathrm{L}^{-1}$} \\
\hline $\mathrm{Ca}^{++}$ & 2.71 & 2.64 \\
\hline $\mathrm{Mg}^{++}$ & 1.64 & 1.44 \\
\hline $\mathrm{Na}^{+}$ & 5.60 & 9.75 \\
\hline $\mathrm{K}^{+}$ & 0.95 & 3.30 \\
\hline \multicolumn{3}{|l|}{ Soluble anions, $\mathrm{mmol} \mathrm{L}^{-1}$} \\
\hline $\mathrm{HCO}_{3}^{-}$ & 6.29 & 2.65 \\
\hline $\mathrm{Cl}^{-}$ & 4.12 & 12.66 \\
\hline $\mathrm{SO}_{4}^{--}$ & 0.49 & 1.82 \\
\hline
\end{tabular}

*Measured at 1:2.5 soils to water ratio. 

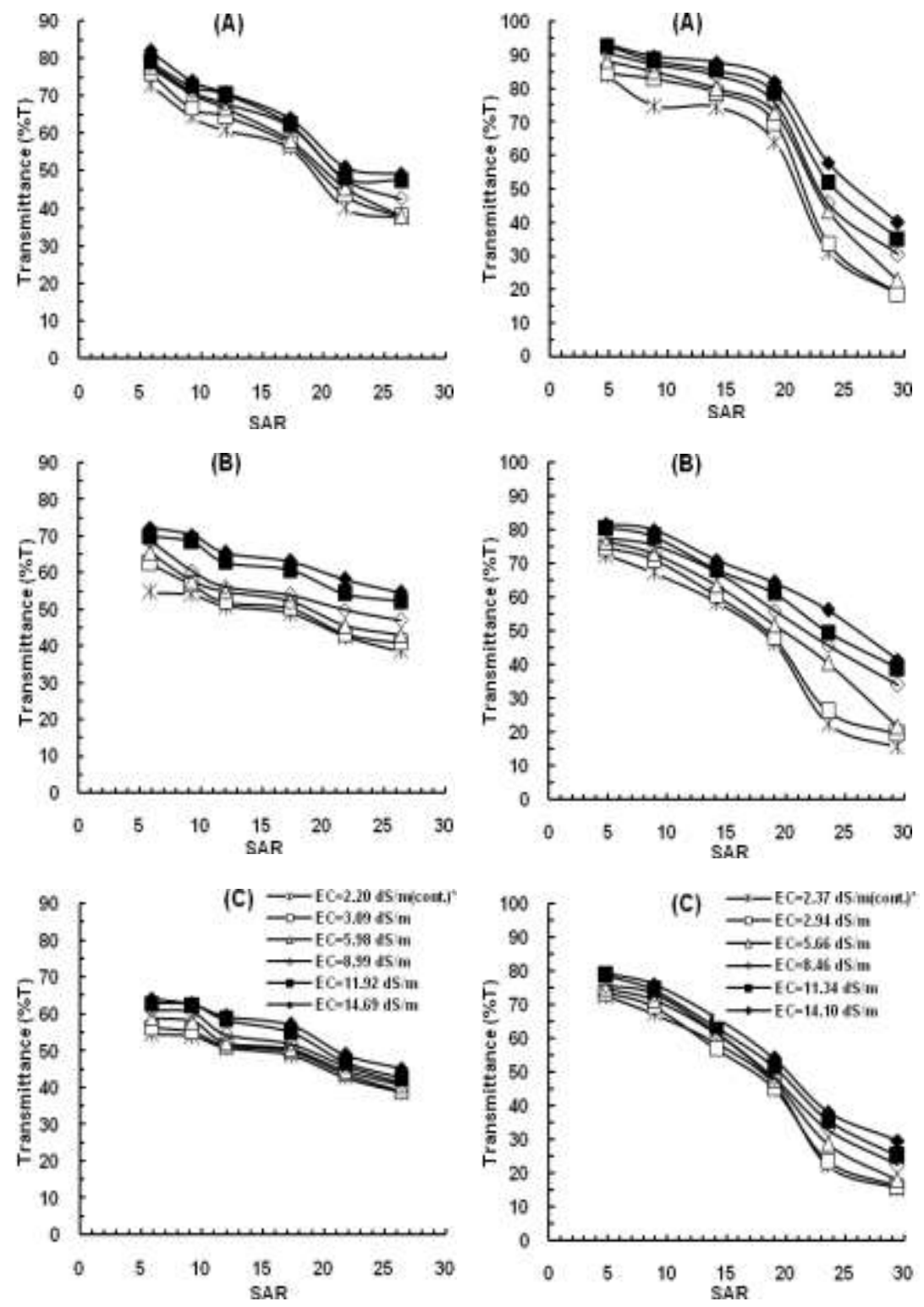

Fig. 1. Relation between $T$ and $S A R$ at varied EC, dS m ${ }^{-1}$ (A) Na-Ca$\mathrm{Mg}$, (B) Na-Ca, and (C) Na-Mg treatments for AL-Rahmania soil (S1); *(cont.), refers to control treatments

Fig. 2. Relation between $T$ and $S A R$ at varied EC, dS m ${ }^{-1}$ (A) Na-Ca$\mathrm{Mg}$, (B) Na-Ca, and (C) Na-Mg treatments for AL- Gemmeza soil (S2); *(cont.), refers to control treatments

Egypt. J. Soil. Sci. 56, No. 4 (2016) 
$\mathrm{Na}-\mathrm{Mg}$ and $\mathrm{Na}-\mathrm{Ca}$ systems

The most important features of (Figs. 1B, 1C 2B and 2C), are: first, no major distinction can be made between the effect of $\mathrm{Ca}$ or $\mathrm{Mg}$ with the two soils when $\mathrm{T}$ method is used. Second, dispersion is considered a continuous process with higher slope at higher SAR values, and no sharp decrease of optical \% $\mathrm{T}$ was observed. Al-Rahmania soil (S1) with its lower clay percent and clay mineral composition exhibits nearly equal affinity for exchangeable $\mathrm{Na}-\mathrm{Ca}$ and $\mathrm{Na}-\mathrm{Mg}$ for SAR values over the range 5-26 and in some sense makes $\mathrm{Na}$ more effective as a dispersing cation. Similar findings are reported by Thellier and Sposito (1989). They reported that the relation between flocculation/dispersion and exchangeable cations for illite depend on the total electrolyte concentration but not on type of bivalent exchangeable cation. This result is confirmed by the work of (Dontsova and Norton 2002). They reported that a negative linear relationship $\left(\mathrm{R}^{2}=82\right.$ to $\left.99 \%\right)$, was observed between $\mathrm{Mg}$ percentage and optical transmittance as an indicator of clay flocculation. Using \% $\mathrm{T}$ approach in the present work revealed, when the three cations have chance to exchange sites, stability of the system is always decreased (dispersion) by an increase of SAR.

Hydraulic conductivity $(K)$ and optical transmission $(T)$

The current study measured $(\mathrm{K})$ as a reference to evaluate the validity of optical transmittance $\% \mathrm{~T}$ for $\mathrm{K}$ prediction (Figs. 3 and 4). Hydraulic conductivity displayed a negative relationship against SAR with the two soils. The hydraulic conductivity measurements showed a decrease (Fig. 3), commences at SAR 12, i.e., $\mathrm{K}$ was $1.3 \mathrm{~cm} \mathrm{~h}^{-1}$ at SAR $12\left(\mathrm{EC} \sim 3.0 \mathrm{dS} \mathrm{m}^{-1}\right)$ and decreased to $0.41 \mathrm{~cm} \mathrm{~h}^{-1}$ at SAR 17.3. This was true with $\mathrm{Na}-\overline{\mathrm{Ca}}-\mathrm{Mg}$ and $\mathrm{Na}-\mathrm{Ca}$ systems. The corresponding drop using optical T approach was detected at SAR 17.3. It was concluded that $\mathrm{K}$ measurements are more sensitive to detect the effect of sodicity and salinity on soil permeability. Adverse effect of soil salinity on sodicity is pronounced with K measurements (Figs. 3 and 4). Soil hydraulic conductivity $(\mathrm{K})$ depends on both SAR and EC. The reduction in hydraulic conductivity (K) might be attributed mainly, to swelling and dispersion of the soil clays. Soil aggregate breakdown causes a reduction in the proportion of macro-pores and consequently a sharp reduction in $\mathrm{K}$ because most of the solution flow occurs through the larger pores (Abu-Sharar et al. 1987).

The curves relating $\mathrm{K}$ and optical $\mathrm{T}$ to soil SAR exhibited similar trend with S2 (Fig. 4). Hydraulic conductivity commences to decrease at SAR 8.87; beyond such point the decrease is well observed suggesting low soil permeability. On the other hand, reduction of optical $\mathrm{T}$ started at SAR 19.05. It means that $\mathrm{K}$ measurements are more sensitive to predict the soil dispersion earlier (SAR 8.87), when compared with the approach of optical transmittance T (SAR 19.05), with $\mathrm{Na}-\mathrm{Ca}-\mathrm{Mg}$ system (Fig. 3A). In general, hydraulic conductivity of S2 was reduced at earlier SAR and plugged the conducting pores, suggesting that the soil may have great instable aggregates which led to high proportion of micro pores and caused $\mathrm{K}$ reduction. The higher the clay content, the greater is the importance of aggregate slaking in controlling water movement in the soil (Mamedov et al. 2001; Levy et al. 2005). 

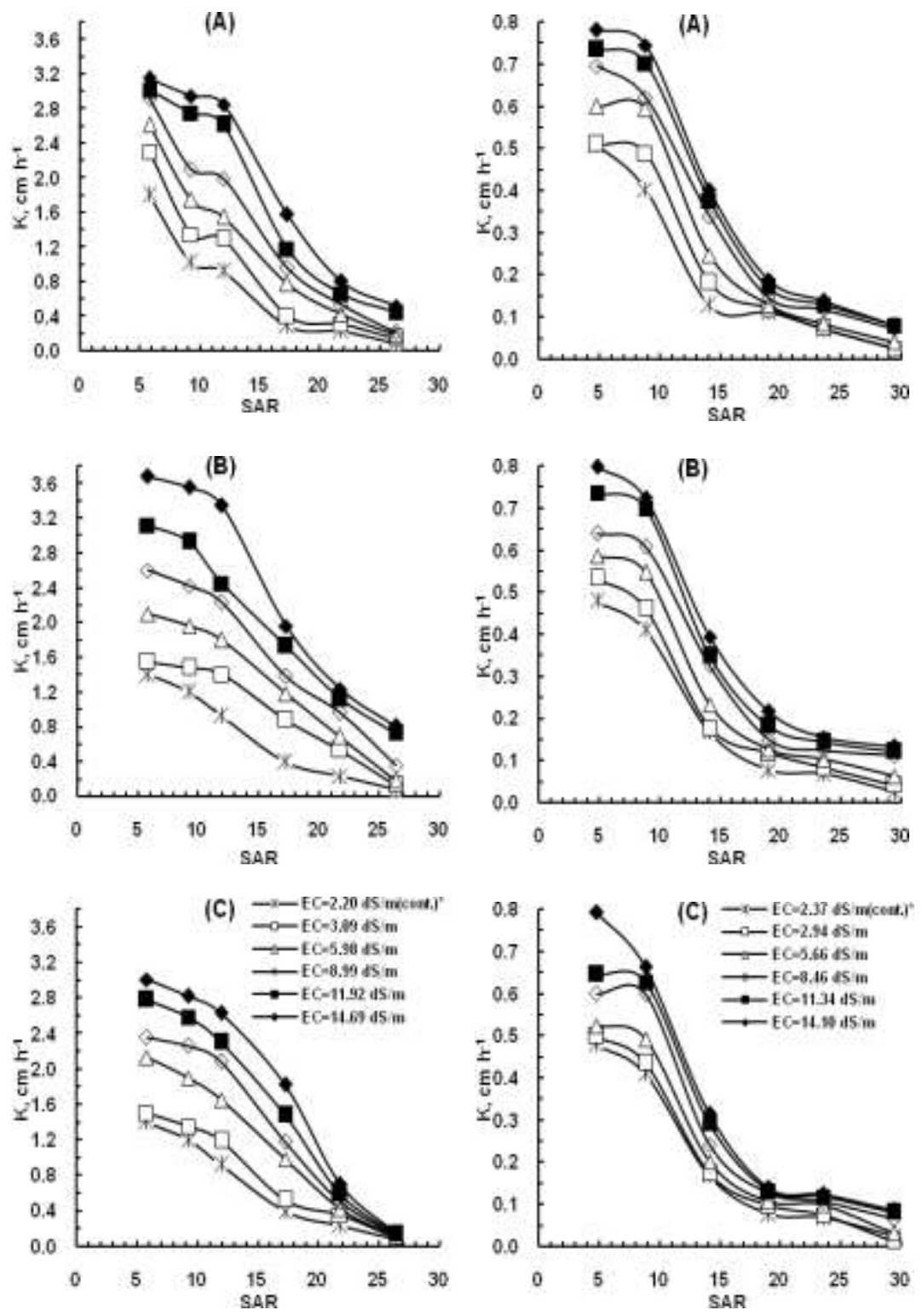

Fig. 3. Relation between hydraulic conductivity $\left(K, \mathrm{~cm} \mathrm{~h}^{-1}\right)$ and SAR at varied EC, $\mathrm{dS} \mathrm{m}^{-1}$ (A) $\mathrm{Na}-\mathrm{Ca}-\mathrm{Mg}$, (B) Na-Ca, and (C) Na-Mg treatments for ALRahmania soil (S1); *(cont.), refers to control treatments

Fig. 4 . Relation between hydraulic conductivity $\left(\mathrm{K}, \mathrm{cm} \mathrm{h}^{-1}\right)$ and SAR at varied EC, $\mathrm{dS} \mathrm{m}^{-1}$ (A) $\mathrm{Na}-\mathrm{Ca}-\mathrm{Mg}$, (B) Na-Ca, and (C) $\mathrm{Na}-\mathrm{Mg}$ treatments for $\mathrm{AL}-$ Gemmeza soil (S2); *(cont.), refers to control treatments

Egypt. J. Soil. Sci. 56, No. 4 (2016) 
Hydraulic conductivity and light transmittance are varied in their basic concepts; $\mathrm{K}$ is based on water volume passing through the soil in definite time, in accordance with Darcy's equation and is usually measured empirically and includes soil properties (tortuosity, pore size distribution, etc.), and percolating fluid viscosity (Shainberg and Letey 1984). On the other hand, \% $\mathrm{T}$ is based on the negative relationship between intensity of transmitted light and absolute number of clay particles per liter. Sharp drop of optical T (dispersion) is considering a good indicator referring to changes of some physical properties, such as hydraulic conductivity and soil infiltration rate. The sharp drop of $\mathrm{K}$ provides that most of macro-pores, which are responsible to water flow, are plugged. One can says, maximum dispersion is not required to reduce the large conducting pores. In general, the current data showed that, the sharp drop of $\mathrm{K}$ was obtained at lower SAR value when compared with optical T approach.

To make use of these findings, which showed that both of $\mathrm{K}$ and $\% \mathrm{~T}$ had a negative relationship with SAR, the following approach is proposed and based on the following givens: first; dividing the wide range of SAR, in the present study to three levels; (5-10), (11-20) and (21-30); second, clay content (\%) values are divided to less or more than $20 \%$. Al-Rahmania soil (S1), represents less than $20 \%$ of clay content and Al-Gemmeza soil (S2), greater than $20 \%$. Data of the three main soil treatments, $(\mathrm{Na}-\mathrm{Ca}-\mathrm{Mg}),(\mathrm{Na}-\mathrm{Ca})$ and $(\mathrm{Na}-\mathrm{Mg})$ were used as plotting points. A linear relationship between $\mathrm{K}$ and optical $\mathrm{T}$ for less than $20 \%$ clay was obtained for the proposed three SAR ranges with varied regression equations. For SAR 5-10: ( $\left.\mathrm{Y}=0.0221 \mathrm{X}-1.3042, \mathrm{R}^{2}=82 \%\right)$; SAR 11-20: $(\mathrm{Y}=$ $\left.0.1571 \mathrm{X}-8.5988, \mathrm{R}^{2}=94 \%\right)$ and SAR 21-30: $\left(\mathrm{Y}=0.0439 \mathrm{X}-1.5528, \mathrm{R}^{2}=89\right.$ $\%$ ). Where, $\mathrm{Y}$ and $\mathrm{X}$ referred to $\mathrm{K}$ and $\% \mathrm{~T}$, respectively. Consequently, the following linear equations represent more than 20\% clay. For SAR 5-10: ( $\mathrm{Y}=$ $0.0221 \mathrm{X}-1.3042, \mathrm{R} 2=86.7 \%)$; SAR 11-20: $\left(\mathrm{Y}=0.0131 \mathrm{X}-0.8086, \mathrm{R}^{2}=74\right.$ $\%)$; and SAR 21-30: $\left(\mathrm{Y}=0.0029 \mathrm{X}-0.0256, \mathrm{R}^{2}=95.9 \%\right)$.

Fifteen soil samples varied in clay content and EC were collected and subjected to $\mathrm{K}$ and optical $\mathrm{T}$ measurements to test validity of the above derived relationships. Soil samples were classified according to their clay content $(<20 \%$ or $>20 \%$ clay), and defined the proper correlation equations. It was observed that predicted and determined $\mathrm{K}$ values have a good relationship, $\mathrm{R}^{2}=98.8 \%$ (Fig. 5). In general, the present proposed method to predict $\mathrm{K}$ showed promising results and needs more future research.

Clay dispersion percent (DP) as related to SAR and EC

Weights of dispersed clay derived from the standard curve relating optical $\mathrm{T}$ against clay concentration were used to calculate soil clay dispersion percentage (Eq. 1), for SAR-EC combinations (Table 2). Al-Rahmania soil (S1) displayed higher (DP) with all treatments. The data also showed that soil aggregates are not always stabilizing by an increase of sodium ions (tendency to dispersion). High clay dispersion of ( $\mathrm{S} 1)$ soil (15\% clay), may be attributed to its lower aggregate stability, i.e., the aggregate is susceptible and disintegration took place very fast. These findings are in agreement with those reported by (Levy et al. 2003 and 2005). 
TABLE 2. Interaction effect of SAR and EC combinations on clay dispersion percentage, for AL-Rahmania soil (S1) treatments; Na-Ca-Mg, Na-Ca and Na-Mg

\begin{tabular}{|c|c|c|c|}
\hline \multirow{2}{*}{$\begin{array}{c}\text { EC, } \\
\mathrm{dS}^{-1}{ }^{-1}\end{array}$} & \multicolumn{3}{|c|}{ Dispersion Percentage } \\
\hline & $\mathrm{Na}-\mathrm{Ca}-\mathrm{Mg}$ & $\mathrm{Na}-\mathrm{Ca}$ & $\mathrm{Na}-\mathrm{Mg}$ \\
\hline \multicolumn{4}{|l|}{ SAR $=5.86$} \\
\hline $1.67^{*}$ & $11.96 \mathrm{k}-\mathrm{n}$ & 23.44 ghij & $23.44 \mathrm{kr}$ \\
\hline 3.22 & $10.29 \mathrm{mno}$ & $18.18 \mathrm{~lm}$ & $22.25 \mathrm{~ms}$ \\
\hline 6.00 & 9.33 no & 16.27 mnop & 20.33 qrst \\
\hline 8.93 & 9.09 no & $14.35 \mathrm{Opq}$ & $19.14 \mathrm{rst}$ \\
\hline 11.20 & 8.85 no & $13.64 \mathrm{pq}$ & $17.94 \mathrm{st}$ \\
\hline 14.25 & $7.42 \mathrm{o}$ & $12.44 \mathrm{q}$ & $16.99 \mathrm{t}$ \\
\hline \multicolumn{4}{|l|}{$\mathrm{SAR}=9.27$} \\
\hline $1.74^{*}$ & 16.99 ghij & 23.92 ghij & $23.92 \mathrm{j}-\mathrm{q}$ \\
\hline 3.02 & $15.55 \mathrm{~h}-1$ & $22.01 \mathrm{ijk}$ & $22.971-r$ \\
\hline 5.98 & $13.40 \mathrm{i}-\mathrm{n}$ & $21.29 \mathrm{ijkl}$ & $21.05 \mathrm{o}-\mathrm{t}$ \\
\hline 9.20 & $12.92 \mathrm{i}-\mathrm{n}$ & $19.62 \mathrm{klm}$ & 19.38 qrst \\
\hline 12.10 & $12.20 \mathrm{j}-\mathrm{n}$ & 14.59 nopq & $18.18 \mathrm{st}$ \\
\hline 14.80 & $11.481-\mathrm{o}$ & $13.64 \mathrm{pq}$ & $17.94 \mathrm{st}$ \\
\hline \multicolumn{4}{|l|}{$\mathrm{SAR}=12.0$} \\
\hline $1.94^{*}$ & $19.14 \mathrm{fgh}$ & $26.32 \mathrm{efgh}$ & $26.32 \mathrm{~h}-\mathrm{m}$ \\
\hline 2.95 & 16.75 ghijk & 25.36 fghi & 25.84 i-n \\
\hline 6.01 & $15.55 \mathrm{hijkl}$ & 23.21 ghij & $25.12 j-p$ \\
\hline 8.59 & $14.83 \mathrm{~h}-\mathrm{m}$ & 22.49 hijk & $23.68 \mathrm{j}-\mathrm{r}$ \\
\hline 12.20 & $13.40 \mathrm{i}-\mathrm{n}$ & $17.94 \mathrm{lmn}$ & 20.81 pqrst \\
\hline 14.80 & $13.16 \mathrm{i}-\mathrm{n}$ & 16.27 mnop & 20.10 qrst \\
\hline \multicolumn{4}{|l|}{$\mathrm{SAR}=17.3$} \\
\hline $2.05^{*}$ & $22.49 \mathrm{f}$ & $27.99 \mathrm{def}$ & 27.99 fghij \\
\hline 3.20 & $21.77 \mathrm{f}$ & $26.79 \mathrm{efg}$ & $27.27 \mathrm{q}-1$ \\
\hline 5.95 & $21.05 \mathrm{fg}$ & 25.12 fghi & 26.79 hijkl \\
\hline 9.20 & $18.42 \mathrm{fgh}$ & 23.92 ghij & $25.36 \mathrm{j}-\mathrm{o}$ \\
\hline 12.10 & $18.18 \mathrm{fgh}$ & $19.38 \mathrm{klm}$ & $23.211-\mathrm{r}$ \\
\hline 14.60 & $17.22 \mathrm{ghi}$ & $17.70 \mathrm{lmno}$ & $21.77 \mathrm{n}-\mathrm{s}$ \\
\hline \multicolumn{4}{|l|}{$\mathrm{SAR}=21.8$} \\
\hline $2.64^{*}$ & $35.65 \mathrm{ab}$ & $33.25 \mathrm{bc}$ & 33.25 bcde \\
\hline 3.02 & $32.54 \mathrm{bcd}$ & $32.78 \mathrm{bc}$ & 32.30 cde \\
\hline 5.92 & $30.62 \mathrm{cde}$ & $30.62 \mathrm{~cd}$ & 31.58 cdef \\
\hline 9.10 & $28.71 \mathrm{de}$ & $27.27 \mathrm{efg}$ & 30.38 defgh \\
\hline 11.82 & $28.47 \mathrm{de}$ & 23.68 ghij & 29.67 efghi \\
\hline 14.50 & $26.32 \mathrm{e}$ & $21.05 \mathrm{jkl}$ & 27.75 fghijk \\
\hline \multicolumn{4}{|l|}{$\mathrm{SAR}=26.4$} \\
\hline $3.14^{*}$ & $38.28 \mathrm{a}$ & $37.32 \mathrm{a}$ & $37.32 \mathrm{a}$ \\
\hline 3.14 & $38.04 \mathrm{a}$ & $34.93 \mathrm{ab}$ & $36.84 \mathrm{ab}$ \\
\hline 6.02 & $37.80 \mathrm{abc}$ & $33.01 \mathrm{bc}$ & $35.17 \mathrm{abc}$ \\
\hline 8.92 & $33.25 \mathrm{bcd}$ & $29.43 \mathrm{de}$ & $34.45 \mathrm{abcd}$ \\
\hline 12.10 & $28.95 \mathrm{de}$ & 25.36 fghi & 33.25 bcde \\
\hline 15.20 & $27.75 \mathrm{e}$ & 23.44 ghij & 31.10 cdefg \\
\hline \multicolumn{4}{|c|}{ LSD $_{05}($ EC X SAR $)$} \\
\hline & 2.97 & 2.44 & 2.70 \\
\hline
\end{tabular}

*refers to control treatments. 


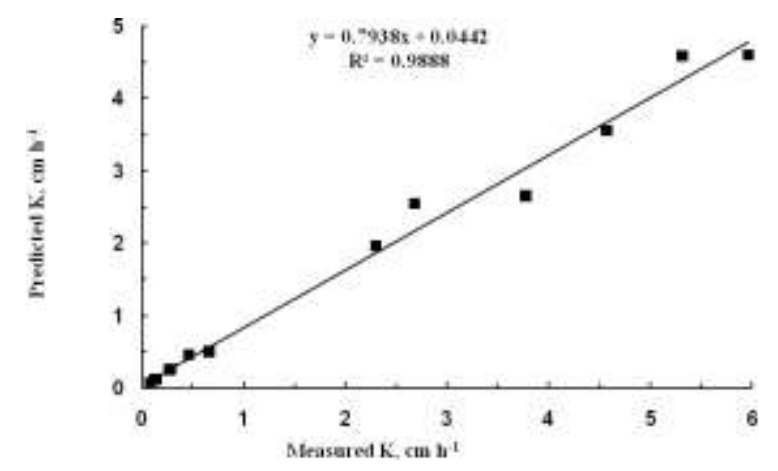

Fig. 5. Measured and predicted hydraulic conductivity $\left(\mathrm{K}, \mathrm{cm} \mathrm{h}^{-1}\right)$

The decrease of K started at SAR 9.27 followed by dramatic reduction at SAR >12, and the corresponding clay dispersion (\%) at SAR 12 (severe reduction) was varied according to soil EC (Table 2). For instance, it decreased from 19.14 to $13.16 \%$ as EC increased from 1.94 to $14.8 \mathrm{dS} \mathrm{m} \mathrm{m}^{-1}$. Dramatic reduction of $\mathrm{K}$ required 24 to $16.5 \mathrm{~g} \mathrm{l}^{-1}$ of dispersed clay to plug soil pores. Further aggregate disintegration due to SAR increase had slight influence on K. Regarding to $\mathrm{Na}-\mathrm{Ca}$ and $\mathrm{Na}-\mathrm{Mg}$ treatments, data of (Table 2), exhibited similar trend as $\mathrm{Na}-\mathrm{Ca}-\mathrm{Mg}$ treatments. Magnesium ions slightly enhanced DP as compared to $\mathrm{Ca}$ ions, when both are complementary ions to $\mathrm{Na}$ on exchange sites. It was postulated that $\mathrm{K}$ reduction was detected at SAR 12 with $\mathrm{Na}-\mathrm{Ca}$ and $\mathrm{Na}-\mathrm{Mg}$ treatments (Table 2). For instance, at SAR 12 and EC range $1.94-14.8$ $\mathrm{dS} \mathrm{m}{ }^{-1}$, clay dispersion percentage decreased from 26.32 to $16.27 \%$, with $\mathrm{Na}-\mathrm{Ca}$ system. The corresponding dispersed clay concentrations needed to plug conducting pores that responsible for water movement were 33.0 to $20.4 \mathrm{~g} \mathrm{l}^{-1}$. There is no much difference with $\mathrm{Na}-\mathrm{Mg}$ treatments when compared to $\mathrm{Na}-\mathrm{Ca}$ treatments. Al-Gemmeza soil (S2), is probably characterized by aggregates with high stability, i.e., clay dispersion (\%) at a given SAR-EC was lower when compared with (S1). High (DP), were associated with inherent properties such as clay mineralogy, $\mathrm{pH}$, sesquioxides and calcium carbonate content may have an important role in determining the response of soil to sodic condition (Sumner and Naidu 1988 and Levy et al. 2003). At given SAR-EC, clay dispersion percentage with Al-Rahmania soil (S1), was nearly twice that of Al-Gemmeza soil (S2), with $\mathrm{Na}-\mathrm{Ca}-\mathrm{Mg}$ treatments, especially at lower SAR. No major distinction was observed between clay dispersion percentage with $\mathrm{Na}-\mathrm{Ca}$ and $\mathrm{Na}-\mathrm{Mg}$ treatments at lower SAR. Results of $\mathrm{K}$ for the three systems showed sharp reduction at SAR 14.16 and EC range $2.26-14, \mathrm{dS} \mathrm{m}^{-1}$. Ranges of clay dispersion percentage were 10.06 to $4.28,18.63$ to 11.78 and 18.63 to $14.13 \%$, with $\mathrm{Na}-\mathrm{Ca}-\mathrm{Mg}$., $\mathrm{Na}-\mathrm{Ca}$ and $\mathrm{Na}-\mathrm{Mg}$ treatments, respectively (Table 3). Their corresponding equivalent clay concentrations needed to reduce K were 32.9 - 14.0, 60.9 - 38.5 and $60.9-46.20$ $\mathrm{g}^{-1}$, respectively. In general, DP decreased within a given SAR as EC increased, due to the adverse effect of salinity (tendency to accumulation) on sodicity, this was true with the all combination treatments. 
TABLE 3. Interaction effect of SAR and EC combinations on clay dispersion percentage, for AL-Gemmeza soil (S2) treatments; $\mathrm{Na}-\mathrm{Ca}-\mathrm{Mg}$, Na-Ca and $\mathrm{Na}-\mathrm{Mg}$

\begin{tabular}{|c|c|c|c|}
\hline \multirow{2}{*}{$\begin{array}{c}\mathrm{EC} \\
\mathrm{dS} \mathrm{m}^{-1}\end{array}$} & \multicolumn{3}{|c|}{ Dispersion Percentage } \\
\hline & $\mathrm{Na}-\mathrm{Ca}-\mathrm{Mg}$ & $\mathrm{Na}-\mathrm{Ca}$ & $\mathrm{Na}-\mathrm{Mg}$ \\
\hline \multicolumn{4}{|l|}{$\mathrm{SAR}=\mathbf{4 . 8 3}$} \\
\hline $1.79^{*}$ & 5.78 pqrst & $10.92 \mathrm{mno}$ & $10.92 \mathrm{rstu}$ \\
\hline 2.98 & $5.35 \mathrm{qrst}$ & 9.85 nор & $10.49 \mathrm{rstu}$ \\
\hline 5.65 & $4.07 \mathrm{rstu}$ & $9.21 \mathrm{nopq}$ & $9.85 \mathrm{stu}$ \\
\hline 8.47 & $3.00 \mathrm{tu}$ & $8.57 \mathrm{opq}$ & $9.42 \mathrm{stu}$ \\
\hline 11.23 & $2.14 \mathrm{u}$ & $7.28 \mathrm{pq}$ & $8.14 \mathrm{tu}$ \\
\hline 14.82 & $2.14 \mathrm{u}$ & $6.64 \mathrm{q}$ & $7.71 \mathrm{u}$ \\
\hline \multicolumn{4}{|l|}{$\mathrm{SAR}=8.87$} \\
\hline $1.98^{*}$ & 9.85 mno & $13.70 \mathrm{~lm}$ & $13.70 \mathrm{pqr}$ \\
\hline 2.85 & 6.21 pqrs & $11.78 \mathrm{mn}$ & 12.63 qrs \\
\hline 5.76 & $5.35 \mathrm{qrst}$ & $10.92 \mathrm{mno}$ & 11.56 qrst \\
\hline 8.52 & $4.50 \mathrm{rstu}$ & 9.64 nop & $10.71 \mathrm{rstu}$ \\
\hline 11.26 & $4.07 \mathrm{rstu}$ & $8.35 \mathrm{opq}$ & $10.06 \mathrm{stu}$ \\
\hline 14.83 & $3.43 \mathrm{stu}$ & $7.49 \mathrm{pq}$ & $9.21 \mathrm{stu}$ \\
\hline \multicolumn{4}{|l|}{ SAR $=14.16$} \\
\hline $2.26^{*}$ & $10.06 \mathrm{mn}$ & $18.63 \mathrm{ij}$ & $18.63 \mathrm{mn}$ \\
\hline 2.88 & 8.14 nop & $17.34 \mathrm{jk}$ & $19.49 \mathrm{~lm}$ \\
\hline 5.74 & $7.49 \mathrm{opq}$ & $15.63 \mathrm{kl}$ & $16.92 \mathrm{mno}$ \\
\hline 8.31 & 5.78 pqrst & $13.49 \mathrm{~lm}$ & $16.70 \mathrm{mno}$ \\
\hline 11.88 & 5.14 qrst & $13.06 \mathrm{~lm}$ & 15.85 nop \\
\hline 14.30 & $4.28 \mathrm{rstu}$ & $11.78 \mathrm{mn}$ & $14.13 \mathrm{opq}$ \\
\hline \multicolumn{4}{|l|}{ SAR $=19.05$} \\
\hline $2.34^{*}$ & $15.42 \mathrm{k}$ & $26.77 \mathrm{f}$ & $26.77 \mathrm{i}$ \\
\hline 2.89 & 12.421 & $25.70 \mathrm{fg}$ & $27.84 \mathrm{i}$ \\
\hline 5.48 & $10.92 \mathrm{~lm}$ & $22.91 \mathrm{~h}$ & $26.12 \mathrm{i}$ \\
\hline 8.69 & $9.42 \mathrm{mno}$ & $20.13 \mathrm{i}$ & $25.27 \mathrm{ij}$ \\
\hline 11.35 & 8.14 nop & $16.92 \mathrm{jk}$ & $23.13 \mathrm{jk}$ \\
\hline 13.85 & $6.64 \mathrm{pqr}$ & $15.20 \mathrm{kl}$ & $21.41 \mathrm{kl}$ \\
\hline \multicolumn{4}{|l|}{ SAR $=23.59$} \\
\hline $2.84^{*}$ & $40.90 \mathrm{c}$ & $52.89 \mathrm{~b}$ & $52.89 \mathrm{c}$ \\
\hline 3.01 & $38.12 \mathrm{~d}$ & $47.32 \mathrm{c}$ & $51.18 \mathrm{c}$ \\
\hline 5.72 & $29.12 \mathrm{~g}$ & $31.69 \mathrm{e}$ & $43.90 \mathrm{e}$ \\
\hline 8.32 & $27.19 \mathrm{~h}$ & $27.41 \mathrm{f}$ & $38.97 \mathrm{f}$ \\
\hline 11.20 & $22.70 \mathrm{i}$ & $24.41 \mathrm{gh}$ & $36.19 \mathrm{~g}$ \\
\hline 13.42 & $19.06 \mathrm{j}$ & $20.13 \mathrm{i}$ & $33.83 \mathrm{~h}$ \\
\hline \multicolumn{4}{|l|}{ SAR $=29.45$} \\
\hline $3.00^{*}$ & $59.53 \mathrm{a}$ & $52.89 \mathrm{~b}$ & $52.89 \mathrm{c}$ \\
\hline 3.00 & $59.53 \mathrm{a}$ & $58.03 \mathrm{a}$ & $64.67 \mathrm{a}$ \\
\hline 5.62 & $52.25 \mathrm{~b}$ & $54.18 \mathrm{~b}$ & $60.39 \mathrm{~b}$ \\
\hline 8.39 & $41.76 \mathrm{c}$ & $37.90 \mathrm{~d}$ & $52.68 \mathrm{c}$ \\
\hline 11.10 & $36.19 \mathrm{e}$ & $32.98 \mathrm{e}$ & $48.61 \mathrm{~d}$ \\
\hline 13.30 & $32.12 \mathrm{f}$ & $31.05 \mathrm{e}$ & $42.83 \mathrm{e}$ \\
\hline \multicolumn{4}{|c|}{ LSD $_{.05}($ EC X SAR $)$} \\
\hline & 1.70 & 1.90 & 2.24 \\
\hline
\end{tabular}

*refers to control treatments

Egypt. J. Soil. Sci. 56, No. 4 (2016) 


\section{Conclusion}

Data of both $\mathrm{K}$ and \% $\mathrm{T}$ displayed a negative relationship with SAR (tendency to dispersion condition as SAR increase). The curves relating either \% $\mathrm{T}$ or $\mathrm{K}$ to SAR were varied in their reflection points which refer to high dispersion and loss of hydraulic conductivity. The empirical equations derived from both $\mathrm{K}$ and \% $\mathrm{T}$ measurements may introduce an easy method to predict soil K. Promising results were obtained when these equations are subjected to evaluation, by using 15 various soil samples with correlation coefficient $\left(\mathrm{R}^{2}=98\right.$ $\%)$. Calculation of dispersion percentage for EC - SAR combination treatments, using $\% \mathrm{~T}$ and standard clay curve (\% $\mathrm{T}$ versus clay content) showed that soil aggregates were not always stabilized by an increase of sodium ions (tendency to dispersion). Dispersion percentage decreased within a given SAR as EC increased due to the adverse effect of salinity (tendency to accumulation) on sodicity.

\section{References}

Abu-Sharar, T.M. (1988) Stability of soil aggregates as inferred from optical transmission of soil suspension. Soil Sci. Soc. Am. J., 52, 951-954.

Abu-Sharar, T.M., Bingham, F.T. and Rhoades, J.D. (1987) Stability of soil aggregates as affected by electrolyte concentration and composition. Soil Sci. Soc. Am. J., 51, 309-314.

Agassi, M. (1996) Soil erosion, conservation, and rehabilitation. Marcel Dekker, Inc., New York.

Arora, H.S. and Coleman, N.T. (1979) The influence of electrolyte concentration on flocculation of clay suspensions. Soil Science 127, 134-139.

Black, C.A. (1965) Methods of soil analysis. Part 1 \& 2. American Society of Agronomy, Inc., Madison, Wisconsin, USA.

Callaghan, M.V., Cey, E.E. and L.R. Bentley (2014) Hydraulic Conductivity Dynamics during Salt Leaching of a Sodic, Structured Subsoil. Soil Sci. Soc. Am. J. 78, 5: 1563-1574. doi:10.2136/sssaj2014.03.0106

Chapman, H.D. and Pratt, P.F. (1961) Methods of analysis for soils, plants and waters. Univ. of California, Div. of Agricultural Science, Riverside.

Curtin, D., Steppuhn, H. and Selles, F. (1994) Clay dispersion in relation to sodicity, electrolyte concentration and mechanical effects. Soil Sci. Soc. Am. J. 58, 955-962.

Dontsova, K.M. and Norton, L.D. (2002) Clay dispersion, infiltration, and erosion as influenced by exchangeable Ca and Mg. Soil Science 167, 184-193.

Endo, T.Y., Amamoto, S., Honna, T. and A.E. Eneji (2002) Sodium-calcium exchange selectivity as influenced by clay minerals and composition. Soil Science 167, 117-125. 
Evangelou,V.P. and Marsi, M. (2003) Influence of ionic strength on sodium-calcium exchange of two temperate climate soils. Plant and Soil., 250, 307-313.

Ezlit, Y. D., McL., J., Bennett, Raine, S. R. and Smith, R. J. (2013) Modification of the McNeal Clay Swelling Model Improves Prediction of Saturated Hydraulic Conductivity as a Function of Applied Water Quality. Soil Sci. Soc. Am. J. 77, 2149-2156. doi:10.2136/sssaj2013.03.0097.

Falstad, J. (2000) Soil condition. transplant status in Burger Draw. Billings Gazette. Prepared by D. G. Steward Page. Burger Draw Comments and Recommendations 6/06/2000.

Frenkel, H., Goertzen, J.O. and Rhoades, J.D. (1978) Effect of clay type and content, exchangeable sodium percentage, and electrolyte concentration on clay dispersion and soil hydraulic conductivity. Soil Sci. Soc. Am. J. 42, 32 -39.

Goldberg, S. and Forster, H.S. (1990) Flocculation of reference clays and arid-zone soil clays. Soil Sci. Soc. Am. J. 54, 714-718.

Hanson, B., S.R. Grattan and A. Fulton (1999). Agricultural salinity and drainage. University of California, Irrigation Program, Davis, USA.

Klute, A. (1986) Methods of soil analysis. Part 1: physical and mineralogical methods. $2^{\text {nd }}$ Ed. American Society of Agronomy, Agronomy Monographs 9(1), Madison, Wisconsin, $1188 \mathrm{pp}$.

Levy, G.J., D. Goldstein and A.I. Mamedov (2005) Saturated hydraulic conductivity of semi-arid soils: combined effects of salinity, sodicity and rate of wetting. Soil Sci. Soc. Am. J. 69, 653-662.

Levy, G.J., Mamedov, A.I. and Goldstein, D. (2003) Sodicity and water quality effects on slaking of aggregates from semi-arid soils. Soil Science 168, 552-562.

Mamedov, A.I., Levy, G.J., Shainberg, I. and Letey, J. (2001) Wetting rate, sodicity and soil texture effects on infiltration rate and runoff. Australian Journal of Soil Research 39, 1293-1305.

Mashali, S. A. (1987) Study on some chemical properties in Egyptian soils. Ph.D. Thesis, Tanta University, Faculty of Agriculture, Egypt.

McIntyre, D.S. (1979) Exchangeable sodium, subplasticity and hydraulic conductivity of some Australian soils. Australian Journal of Soil Research 17, 115-120.

Nikos, J.W., Bauder, J.W. and Pearson, K.E. (2003) Basics of salinity and sodicity effects on soil physical properties. Land Resources and Environmental Sciences Department. http://waterquality.montana.edu./docs/methane/basics.pdf (verified 15 Dec. 2006).

Page, A. L., Miller, R. H. and Keeney, D. R. (1982) Methods of Soil Analysis. 2nd Ed., American Society of Agronomy, Madison, WI., USA.

Quirk, J.P. and Schofield, R.K. (1955) The effect of electrolyte concentration on soil permeability. J.of Soil Science, 6: 163-178.

Egypt. J. Soil. Sci. 56, No. 4 (2016) 
VALIDITY OF LIGHT TRANSMITTANCE TO PREDICT SOIL HYDRAULIC ..737

Quirk, J.P. (2003) Comments on "Diffuse double-layer models, long-range forces, and ordering of clay colloids". Soil Science Society of America Journal 67, 1960-1963.

Shainberg, I. and Letey, J. (1984) Response of soil to sodic and saline conditions. Hilgardia 52: 1-57.

Shainberg, I. and Kaiserman, A. (1969) Kinetics of the formation and breakdown of Camontmorillonite tactoids. Soil Science Society America Proceeding 33, 547-551.

Soil Survey Staff (2010) Keys to Soil Taxonomy, United States Department of Agriculture (USDA), Natural Resources Conservation Service (NRCS), Washington, DC, USA, Eleventh Edition.

Sparks, D.L., Page, A.L., Helmke, P.A., Loppert, R.H., Soltanpour, P.N., Tabatabai, M.A., Johnston, C.T. and Sumner, M.E. (1996) Methods of soil analysis: Chemical Methods, Part 3. ASA and SSSA, Madison, WI.

Seifert, C. J. Ivan Ortiz-Monasterio and Lobell, D.B. (2011) Satellite-Based Detection of Salinity and Sodicity Impacts on Wheat Production in the Mexicali Valley. Soil Sci. Soc. Am. J. 75, 699-707. doi:10.2136/sssaj2010.0233.

Sposito, G. (1984) The surface chemistry of soils. Oxford University Press, New York.

Sumner, M.E. (1993) Sodic soils: New perspectives. Australian Journal of Soil Research 31, $683-750$.

Sumner, M.E. and Miller, W.P. (1996) Cation exchange capacity and exchange coefficients, In: Sparks, D.L., Page, A.L., Helmke, P.A., Loppert, R.H., Soltanpour, P.N., Tabatabai, M.A., Johnston, C.T. and Sumner, M.E. (Eds.), Methods of Soil Analysis: Chemical Methods, Part 3. ASA and SSSA, Madison, WI, pp. 1201-1230.

Sumner, M.E. and Naidu, R. (1988) Sodic soils. Oxford Univ. Press., New York.

Tedeschi, A. and R. Dell' Aquila (2005). Effects of irrigation with saline waters at different concentrations, on soil physical and chemical characteristics. Agricultural Water Management 77, 308- 322.

Thellier, C. and Sposito, G. (1989) Influence of electrolyte concentration and exchangeable cation on the flocculation of silver hill illite. Soil Sci. Soc. Am. J. 53, 711-715.

(Received:8/2/2015;

accepted : $1 / 3 / 2017$ ) 


\section{صلاحية الضوء النافذ للتنبؤ بالتوصيل الهيدروليكى بالتربة فى بلائو \\ الأراضى المتأثرة بالأملاح}

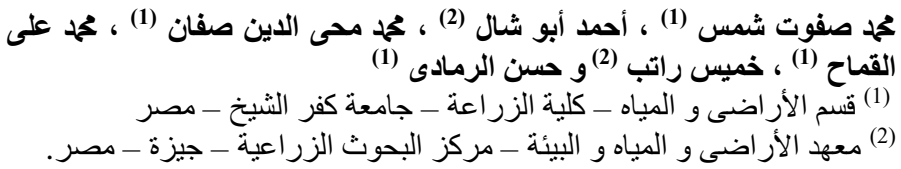

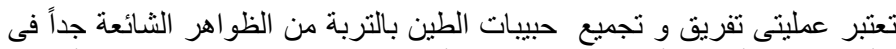

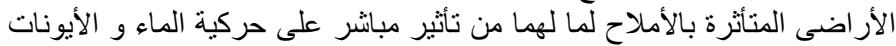

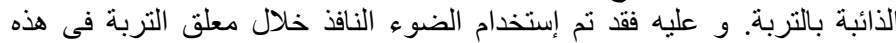

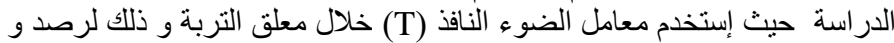

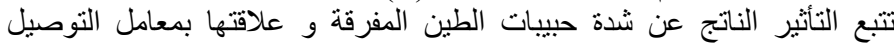

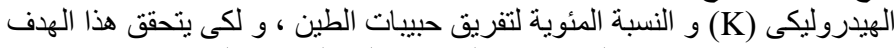

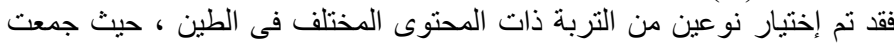

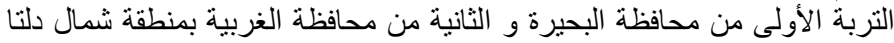

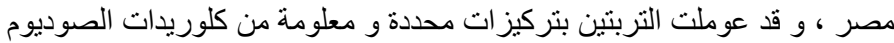

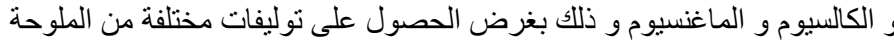

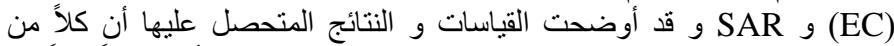

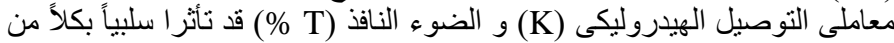

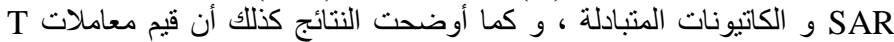

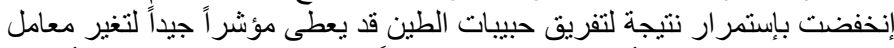

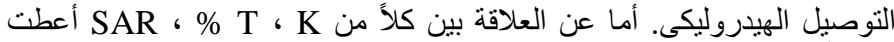

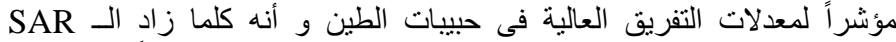

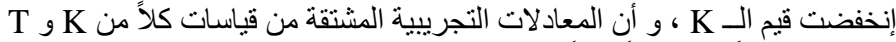

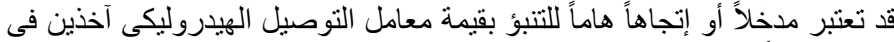

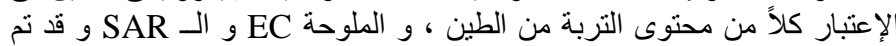

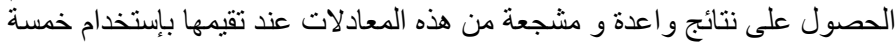

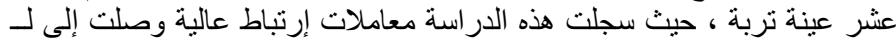

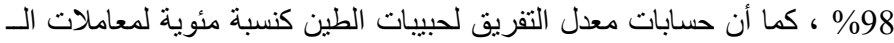
SAR-EC

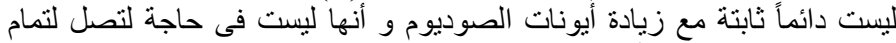

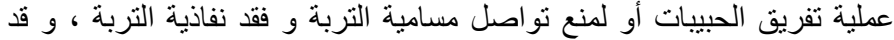

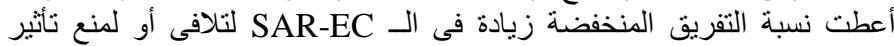

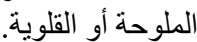

